\title{
POLITICS OF LAW OF RISK MANAGEMENT APPLICATION IN THE MANAGEMENT OF THE STATE- OWNED ENTERPRISES IN INDONESIA
}

\author{
Prasetio \\ Faculty of Law Al-Azhar University, Indonesia \\ E-mail: prasetio@gmail.com
}

\begin{abstract}
Risk management within the State-Owned Enterprises (SOEs) is formally regulated; however, risk-conscious cultures have not been seen as strategic needs. Orientation on opportunity, profit growth, and market share still dominate decision making. Risk management is still often considered to hamper the process and slow growth. Risk awareness values are considered important to build and entrenched in an ongoing system so that risk awareness is internalized in every decision-making process. The following descriptions are based on literature studies and empirical experiences the authors describe the ideas and experiences of introducing and building risk awareness culture in the environment of state enterprises in the early stages. UU NO. 1 of 2003 on SOEs does not regulate in detail about risk management on SOEs. The existence of risk management is contained in the Regulation of the Minister of SOE numbered PER-09 / MBU / 2012. This regulation contains amendments to Article 12 paragraph 10 PER-01 / MBU / 2011 concerning the implementation of Good Corporate Governance in State-Owned Enterprises, and is regulated in more detail at the Decree of the Secretary of the Ministry of SOEs No. SK-16 / S.MBU / 2012 on the assessment indicators / parameters and Evaluation of Good Corporate Governance Implementation on SOEs. The legal politics that exist despite their existence, but lacks a strong philosophical meaning because the rules are not supported in detail in regulation at the level of law.
\end{abstract}

Keywords: Political Law, State Own Enterprise, Risk Management, Management

\section{A. INTRODUCTION}

Economic development in Indonesia has been running after independence with the basics of managing the economy of the country which is governed in the Article 33 of The 1945 Constitution. That the duty of the state is to make people prosperous with all their potential. Even in Article 33 Paragraph (2) of the 1945 Constitution stated "Production branches that are important for the state and which affect the livelihood of the people are controlled by the state". In the 
explanation of the provision stated that the production branch which is important for the State is "Strategic production activities relating to justice, security and national stability that provide prosperity for all people, Production branches that affect the livelihood of many people is "The production of vital goods and services such as water, energy and public transport" and "the production of goods and services perceived vital to human life in a certain period of time, controlled by the State is " it means it shall not be owned by the State, except to guarantee the function of control by the State in order to advance the welfare of the people". Thus, supposedly, the understanding of the authority of the State (in this case often through SOES (State-owned enterprises) as operators) to control the livelihood of the people is limited to the rights of the national property / property of the people, in other words, actually the ownership right is still on the side of the Indonesian people as citizens of the Republic of Indonesia.

Article 33 paragraph (3) of the 1945 Constitution reinforces the role of SOEs as agents of development, SOEs as the long-handed of government is a development agent to strive for the greatest prosperity of the people. To carry out the mandate, the Government has formed a technical body which then takes the form of State-owned Enterprises. Article 1 paragraph 1 of Law No. 19 of 2003 About State-owned enterprises mention, SOEs is a business entity which is wholly or partly owned by the state through direct participation derived from separated state assets. SOEs is one form of business entity in the world economy. Business entities that move with the form of SOEs is usually the body that controls the potential sector that is processed to fulfill the livelihood of the people. The role of SOEs in conducting production activities, especially in production branches that are important for the State and affect the livelihood of the people, therefore, the existence of the SOE is basically an implementation of the role of the state as a regulator, and also as an entrepreneur.

This is in line with what stated by W. Friedmann in the theory of "mixed economic system" that the state has 4 functions, namely as a "regulator, entrepreneur, provider, and umpire". A mixed economic system is an economic system that features characteristics of both capitalism and socialism. A mixed economic system protects private property and allows a level of economic freedom in the use of capital, but also allows for governments to interfere in economic activities in order to achieve social aims. According to neoclassical theory, mixed economies are less efficient than pure free markets, but proponents of government interventions argue that the base conditions such as equal information and rational market participants cannot be achieved in practical application (Mixed Economic System https://www.investopedia.com/terms/m/mixed-economic-system.asp\#ixzz56ZY0nN2g ). 
The era of globalization is increasingly asserting that SOEs are no longer operating in a vacuum of competition. The ASEAN Economic Community (MEA) Agreement, the ASEAN-China Free Trade Area (ACFTA) are some of the forms of globalization. The limits of the 'business competition' space are decreasing.Even now has emerged the era of industrial 4.0. The current business movement in the era of digitalization is known to require a comprehensive strategic move. The government as regulator also needs to prepare basic infrastructure and supporters to support the movement of industrial era 4.0. One of them, he highlighted the connectivity of the internet network in Indonesia, according to him connectivity in Indonesia is still inferior to some countries in the ASEAN region.

SOEs will inevitably have to respond to it by being aware of the competition and anticipation of business risks. The importance of risk management in the environment of SOEs has received serious attention since more than 15 years ago. This awareness, among others, appears in the emergence of the provisions of Article 28 paragraph (2) Kep-117/M.BU/2002 which states that in addition to annual reports and financial reports, SOEs should disclose important matters for decision making by owners of stock, shareholders, creditors, and other stakeholders. This is about the material risk factors that can be anticipated, including an assessment of management over business climate and risk factors. Furthermore, Article 14 paragraph (8) Kep-117/M.BU/2002 states that the Insurance and Business Risk Committee is tasked with periodic appraisal and recommendation on business risks and the type and amount of insurance that must be covered by SOE in relation to business risk. Minister of SOE Regulation No. 1 of 2011 on the Implementation of Good Corporate Governance (GCG) in SOEs also emphasizes this. In the sixth section of the regulations, which regulates Risk Management, mentioned in Article 25 (1), that the Board of Directors in any decision-making / action, shall consider business risks. (2) The Board of Directors shall build and implement an integrated corporate risk management program that is part of the implementation of the GCG program. Implementation of risk management program can be done, by: a. to form a separate working unit under the Board of Directors; or b. gave the assignment to the work units and relevant to running the risk management function. Furthermore, it is said that the directors must submit a risk management profile report and handling it together with the company's periodical report.

Although the regulation is already set regarding the importance of risk management, however some of the conditions indicates the opposite condition. The Ministry of SOEs recorded 24 companies that suffered losses of Rp 5.852 trillion in the first quarter of 2017. The amount is reported to be higher than the same period last year, which was Rp5.826 trillion. Due to the loss, Finance Minister Sri Mulyani freed the SOE from the obligation to pay dividends to the 
state in 2018. 24 state-owned enterprises suffered losses due to competitiveness and efficiency and 11 other SOEs are still losing money due to restructuring process (http://www.bbc.com/indonesia/indonesia-41107226). At the end of December 2017, although the number decreased, but the fact that state-owned enterprises are losing money is still in 2 digits. The cause of SOEs are losing money due to compete in the market, and some have experienced losses of up to tens of years. There is also a state that suffered losses due to the inability of management to generate profit. Among the losing state-owned companies, there are two state-owned companies with the largest loss, namely, Garuda Indonesia and Krakatau Steel each above Rp1 trillion. Specifically for Garuda, a loss more because the company caught up in war fare and international routes that are not efficient. While Krakatau Stell losses swell caused, among others, the existence of dumping of steel from China

(http://republika.co.id/berita/ekonomi/makro/17/12/22/p1bqo7354-rini-13-bumn-masihrugi-pada-2017).

The rapid development of business and coupled with the complexity of the business world, in the end demands the manager of SOEs to always devote their attention to the existence and growth of the company in the midst of increasingly fierce business competition. The era of complexity with a variety of business risks which demand the readiness of companies to be able to answer the challenge of competition in global competition. Business risk in various forms and sources creates both challenges and uncertainties in building a healthy and strong business. The awareness of managing business risks to be an opportunity is the dream of all companies, but the risks are not very simple in a business climate that has a high degree of uncertainty. Therefore, risk calculation in every decision-making process should be an important consideration of management in order to be able to effectively manage the risks it faces. Failure to understand every risk in business activity can result in the company getting sick and this event will be very harmful to SOEs, harming the state and harming the community.

\section{B. PROBLEM STATEMENT}

According to the introduction, this article analysis how to construct the politics of law of risk management application in the management of the stateowned enterprises in Indonesia?

\section{RESEARCH METHOD}

This research uses normative method. Legal material is collected through literature study with primary legal materials in the form of Law Number 19 of 2003 on State-Owned Enterprises (SOEs), Related Government Regulation and Minister of State-Owned Enterprises Regulation No. 1 of 2011 on the 
Implementation of Good Corporate Governance, as well as several other supporting regulations. Primary legal material consists of journals, books, news and articles related to the management of SOE and risk management. To confirm the material analysis of legal materials, researchers also conduct focus group discussions with academics and practitioners in the field of companies and SOEs.

\section{DISCUSSION AND RESEARCH RESULT}

\section{Urgency on the Implementation of Risk Management in the Management of SOEs in Indonesia}

Risk is the uncertainties that lead to the occurrence of various levels of profitability that worsen or even cause harm. Risks, as explained by Djojosoedarsono in Principles of Risk Management and Insurance (1999: 1-2), are as follows:

a. Risk is a variation of the results that can occur during a certain period.

b. Risk is uncertainty that may give rise to loss events.

c. Risk is the uncertainty over the occurrence of events.

d. Risk is the spread / deviation of actual results from the expected results.

e. Risk is the probability of a result / outcome that is different than expected.

In the context of financial science (finance) and economics, risk is the volatility or standard deviation of net cash flow of a company / business unit. The risk exists when there is a possibility that the result of an event is not just one and the largest outcome is unknown (Wimboh Santoso dan Heriantoro, 2003 : 76). Masyhud Ali, dalam Manajemen Risiko, Strategi Perbankan dan Dunia Usaha Menghadapi Tantangan Globalisasi Bisnis (Masyhud Ali, 2006 : 101), said that risk is the probability of a possible disaster or loss. Therefore, risk from a bank standpoint is defined as the probability of a worsening situation (bad outcome). This definition implies that risk relates only to situations in which a negative outcome can occur at any time and that the probability of occurrence can be estimated. Thus, it can be concluded that risk is always associated with bad outcomes due to something very closely related to uncertainty. However, there is a difference between uncertainty and risk. Risk is a known uncertainty of the 
probability level of its occurrence and there is supporting data / information about the probability of its occurrence. Meanwhile, uncertainty is a condition that indicates there are several possible events and each occurrence causes different results.

Riagel and Miller, in his book Insurance Principles and Practices, quoted back by Emmy Pangaribuan Simanjuntak in the Insurance Law: The Principles of Indemnification, Fire and Soul (Emmy Pangaribuan Simanjuntak, 1980 : 6), distinguish the economic risks of two groups. The main basis of this classification is the nature of the consequences of the risk. First, the risk is speculative or chancy (speculative risk). This risk is likely to cause losses on the one hand, but also allows for benefits on the other. In other words, it is said to be a speculative risk if the result could be a loss or gain. Second, the risk is pure. Pure risk does not mix the two possible elements of profit and the element of possible loss, but always bring unfortunate consequences. The risks to a person as a result of a fire, a result of an earthquake, or loss of property of a particular person can befall everyone, but not sure will befall whom. In practice, there are many risks faced by the company. Some of the most common risks in business processes of a business entity, among them, are marketing risk, production risk, financial / liquidity risk, credit risk, legal risk, compliance risk, procurement risk, equipment risk, technological risk, and human resources risk. Reliable, fast, and up to date riskrelated information will facilitate risk management or risk management in a company. Given the diversity and complexity of risk, risk management is required as a formal discipline into a series of actions in controlling those risks. Risk management is an ongoing process in an attempt to suppress the adverse effects of these risks. This emphasizes the importance of accounting science and risk management for the management of an organization of the company in taking a prudent decision by considering and observing the risks that potentially bring harm to the company.

One definition that is widely used globally describe the definition of risk management is Enterprise Risk Management (ERM), which was formulated by the Committee of Sponsoring of the Treadway Commission (COSO). Risk management or ERM is described as follows:

"Enterprise risk management is a process effected by an entity’s board of directors, management and other personnel, applied in strategy setting and across the enterprise, designed to identify potential events that may affect the entity, and manage risks to be within its risk appetite, to provide reasonable assurance regarding the achievement of entity objectives." 
This definition includes five very important elements in understanding risk management:

a. Process: Risk management is a process, not a part / division / element of the company. Therefore, risk-conscious culture must be attached to all elements within the company, not the responsibility of one part or element alone

b. Applied in strategy setting \& across the enterprise: The risk management process is applied to the process of determining corporate strategy and covering all layers / line of companies. Whatever the strategy set by the company, it must go through a risk-based review process.

c. Identify potential events: The implementation of the risk management process should be able to identify every possible risk that will occur. In this case, the identified not only the real risks will arise, but also potential risks.

d. Manage risks to be within their risk appetite: Ensure these possible risks are tolerable or manageable, not eliminated (because it is not possible eliminate a risk), in accordance with agreed risk tolerance limits.

e. Reasonable assurance: Implementation of risk management process in a strategy is expected to provide assurance of achieving reasonable / logical results, not maximum results.

SOEs that only prioritize business development and ignore risk management have the potential of unsustainable growth (not lasting). Businesses that grow too fast, generate huge profits in a short period of time, if not followed by adequate risk management and manageable governance, growth will not last long. Ricard A. Posner proposes a theory of economic law that decomposes in his article entitled "economic analysis of law", which emphasizes that a rule of law that regulate the economic activities must be able to provide three main values in the field of economy, namely: economic value, economic utility, and economic efficiency" (Richard A. Posner, 1994).

The bankruptcy of Enron Corporation and various companies in it's generation that shocked the financial world in 2001, occurred because of the neglect of risk management. Rapid economic growth often leads to excessive optimism. The large number of window dressings on the books of major corporations was triggered by the desire to achieve high growth due to shareholder demands that wanted large and fast results. This scandal further prompted various circles to question accounting practices and activities in US corporations in general. In turn, the scandal prompted the creation of The 
Sarbanes-Oxley Act (SOX) in 2002, a US federal law that requires all directors of public companies to affix their approval to the accuracy of the company's financial statements.

In addition to apply to all public companies, this law also applies to public accountants in the United States. SOX also gives wider authority to the board of directors to review the company's financial statements. Broader authority is also given to the external auditors of the company. SOEs as a form of company which all or most of its stock comes from separated state assets, has a role as a pioneer and / or pioneer in business sectors that have not been sought by the private sector in order to achieve prosperity as much as possible for the people. Besides that, SOEs also have a strategic role as implementers of public services, balancing the great powers, and assist in the development of small businesses / cooperatives.

\section{Political Law of Risk Management Aplication in the Management of State-Owned Enterprises in Indonesia}

Based on Law No. 19/2003 there are 2 forms of SOEs namely:

a. Persero Company, hereinafter referred to as "Persero", is a state-owned limited liability company whose stock is divided into shares of all or at least $51 \%$ (fifty one percent) of its shares owned by the Republic of Indonesia with the main objective advantage. Forms of Persero there is "Open", namely Persero stock and the number of shareholders meet certain criteria or Persero who do public offering in accordance with the laws and regulations in the field of stock markets.

b. Public Company, hereinafter referred to as "Perum", is a State-Owned Enterprise wholly owned by the state and is not divided into shares, aiming at general benefit of providing high quality goods and / or services while pursuing profit based on company management principles.

Currently there is a duality of regulation on the management of stateowned enterprises. First, the arrangement which assumes that State-Owned Enterprises is a mere business entity. Secondly, the regulation that assumes that the management of SOE Persero seen from the aspect of capital included into the State Finance, Uncertainty of arrangement is an unclear legal political implication which is reflected from the management of SOE Persero with risk aversion, and a nonuniform application and enforcement of laws that are not optimal in supporting the role of SOEs in the development of the Indonesian economy. The responsibility of the management of SOEs Persero or the organs of the state-owned Persero is to be civil and State responsibility is limited in accordance with the shares owned. Limited liability of the 
Company's organs and the State can be breached if it exceeds the management authority of the piercing the corporate veil.

Sunaryati Hartono in her Political Law Towards One National Legal System sees legal politics as a tool, or the means and measures that can be used by the government to create a national legal system that is desired and with the national legal system that will be achieved the Indonesian people's dream (Sunaryati Hartono, 1991 : 128). Satjipto Rahardjo defines political law as the activity to choose and how to use to achieve a social goal and a particular law in society (Satjipto Raharjo, 2000 : 35). Political law of a country is different with the political laws of other countries. This difference is due to differences in the background of historical, world-view, sociocultural, and the political will of each government. In other words, legal politics is local and particular (only valid from and to certain countries only), not universal. But that does not mean that the political law of a country ignore the reality and the politics of international law. The definition of legal policy, including the process of making and implementation of law that can indicate the nature and direction of which the law will be built. The political law provide the basis for a more appropriate process of law formation, the situation and condition, culture and value that lived in society by paying attention to society requirement to law itself (Mahfud MD, 2009: 9). In other words, the political law can be divided into two dimensions, namely first, political law which is the basic reason for the holding of a legislation. Second, the purpose or reason that arises behind the enactment of a legislation.

Risk management is the wave of new solutions to address the challenges of managing a modern business. Risk has become the latest topic of management, and companies have raised risk managers in senior management to provide visibility and strength of risk management. If there is an opinion that it is easy to say no, but difficult to make money, then we change that paradigm to, "no risk, no business." Thus, the risk is no longer seen as things to be eliminated altogether, but rather by looking at the presence of risk, helping to do good planning (Prasetio, 2015).

The application of effective risk management will help the company to minimize the impact of risks that could potentially hinder the company in achieving its goals, as well as maximize value for its stakeholders. The purpose of the application of risk management in the insurance industry basically not different from other industries in order to minimize and manage risks that have a negative impact on the purpose, vision, and mission of the company. In the basic theory of risk management, its phases is to determine the context (scope and purpose), risk identification, risk analysis, and control 
risks. Because risk is dynamic, then it should always be done revieu and monitoring. To implement it, risk management guidelines are required that may contain risk management policies and procedures. In addition, there must be an implementation so that a risk management organization structure is required and who is involved in its implementation.

The regulation of the practical risk management of SOEs contained in the Regulation of the Minister of SOE numbered PER-09/MBU/2012. This regulation contains amendments to article 12, paragraph 10 PER01/MBU/2011 about the implementation of Good Corporate Governance (GCG) in SOEs. In order to implement Good Corporate Governance, has been set the Decree of the Minister of SOE Number Kep-117/M-MBU/2002 dated July 31, 2002 on Implementation of Good Corporate Governance Practices in State-Owned Enterprises (SOEs); b. that in connection with the renewal of the law in the field of limited liability companies and state-owned enterprises, as well as pay attention to the development of the business world is increasingly dynamic and competitive, so to further improve the implementation of good corporate governance, it is necessary to make adjustments to the Decree of the Minister of SOE No. Kep-117/M-MBU/2002 dated 31 July 2002; c. that based on the considerations as meant in letters $a$ and $b$ above, it is necessary to stipulate Regulation of the Minister of SOEs on the Implementation of Good Corporate Governance (GCG) In State-Owned Enterprises; Regulation of the Minister of SOE numbered PER-09/MBU/2012. Replaces Regulation of the Minister of State-Owned Enterprises (SOEs) Number PER-01/MBU/2011.

According to Article 44 (1) Regulation of the Minister of SOEs 01/2011, SOEs shall take measurements on the quality of GCG implementation periodically every 2 (two) years in 2 forms; 1 ) assessment of GCG implementation and 2) on follow-up recommendations of improvements from the results of the previous assessment. In principle the one that will do the evaluation is SOE itself (self-assessment), while the implementation of the assessment performed by an independent appraiser who is competent and should be appointed by the Board of Commissioners. Technically, it is further elaborated into the Decree of the Secretary of the Ministry of SOEs No. SK16/S.MBU/2012 (SK-16/2012) discusses the Indicators / Parameters of Assessment and Evaluation of the Implementation of Good Corporate Governance on SOEs on June 6, 2012. This Decree (SK-16/2012) contains 153 points of GCG parameters grouped into 43 indicators and 6 aspects. The six aspects consist of:

a. Commitment to the implementation of sustainable governance,

b. Shareholders and GMS / owners of stock, 

c. The board of Commissioners / Supervisory Board,
d. The board of directors,
e. Disclosure of information and transparency, as well as
f. Other aspects.

\section{E. CLOSING}

Building a risk-conscious culture within a company is a universal movement, a movement that reaches and engages everyone inside the company. Building a risk conscious culture is also an attempt to build a new culture, not just to awaken or modify the old culture. Risk-conscious culture brings the implications of creating something that does not yet exist, especially in nonfinancial corporations that have not made risk management systematically and integrated as a tradition. Political law in setting about the risk management aims at the desire of vigilance to anticipate the global competition. However, the position is at the technical level rules, which in the implementation on the Law on SOEs tend to be less.

Political law management of SOEs Persero in the future should show a paradigm change in the management of SOEs Persero through the law as a means of renewal which includes the renewal of legislation that reflects the norms that reflect the principle of fairness and legal certainty, and expediency. The renewal process in the management of SOEs, that support decision making more quickly, efficiently, and more accountable, and pay attention to risk management aspects related to the management of SOEs. It is necessary for the harmonization of legislation that has the intersection with the Limited Liability Company Law and the SOEs Law which becomes the operational basis of SOEs Persero. In starting, understanding, awakening, and building risk conscious culture, the CEO becomes a key actor. Without the highest management support, risk-conscious culture will not be maximized even though supported by executives with strong professional skills in risk management. Considering that building risk conscious culture is also management changes (tone of the top change management), required the socialization of the change to all parts in the company down to the smallest unit and the lowest unit. 


\section{BIBLIOGRAPHY}

\section{Books:}

Emmy Pangaribuan Simanjuntak, 1980, Hukum Pertanggungan: Pokok-Pokok Pertanggungan Kerugian, Kebakaran dan Jiwa (Insurance Law; Principle of Indemnification, Fire, and Life). Seksi Hukum Dagang, Fakultas Hukum, Universitas Gadjah Mada: Yogyakarta.

Hartono, Sunaryati 1991, Politik Hukum Menuju Satu Sistem Hukum Nasional (Poltics of Law Towards the Unity of the National Justice System), Alumni: Bandung.

Masyhud Ali, 2006, Manajemen Risiko, Strategi Perbankan dan Dunia Usaha Menghadapi Tantangan Globalisasi Bisnis (Risk Management, Banking Strategy, and the Business World Faces The Challenge of Globalization), Raja Grafindo Persada: Jakarta.

Prasetio. 2015, It Goes Without Saying, Rayyana Komunikasindo: Jakarta.

Richard A. Posner. 1994, Economic Analysis of Law, Ed.4, Harvard University Pres:s USA.

Satjipto Raharjo, 2000, Ilmu Hukum (Legal Sciences), Citra Aditya Bakti: Bandung.

Soeisno Djojosoedarsono. 1999, Prinsip-Prinsip Manajemen Risiko dan Asuransi (Principles on The Risk Management and Insurance), Salemba Empat: Jakarta..

Mahfud MD, 2009, Politik Hukum Di Indonesia (Politics of Law in Indonesia), Rajawali Pers: Jakarta.

Wimboh Santoso dan Enrico Heriantoro, 2003, Market Risk di Perbankan Indonesia. Kajian Stabilitas Keuangan No. 1, Juni 2003 (Risk Market in The Indonesia Banking. The Financial Stability Studies), Bank Indonesia: Jakarta.

\section{Internet}

Mixed Economic System https://www.investopedia.com/terms/m/mixedeconomic-system.asp\#ixzz56ZY0nN2g , accessed 28 January, 2018

http://republika.co.id/berita/ekonomi/makro/17/12/22/p1bqo7354-rini-13-bumnmasih-rugi-pada-2017, accessed 1 February, 2018

http://www.bbc.com/indonesia/indonesia-41107226, accessed 28 January , 2018 